\title{
Comparative studies in human and armadillo derived Mitsuda lepromin
}

\author{
K JESUDASAN, M CHRISTIAN, \\ C J G CHACKO \& J S KEYSTONE* \\ Schieffelin Leprosy Research and Training Centre, Karigiri 632106, \\ India; *Toronto University, Canada
}

Accepted for publication 21 February 1985

\begin{abstract}
Summary This study is on 2 groups of leprosy patients using the Mitsuda lepromin test. The first group of 37 patients received (). $1 \mathrm{ml}$ of both human (Lepromin-H) and Armadillo lepromin (Lepromin-A) in concentrations of 40 million bacilli per $\mathrm{ml}$. The average readings for Lepromin-A and $-\mathrm{H}$ were $4.7 \mathrm{~mm}$ and $2.1 \mathrm{~mm}$ respectively. Using Nested analysis of variance, the Lepromin-A readings were found statistically significantly $(2 \cdot 2$ times $)$ higher than the Lepromin-H readings. The second group of 60 patients received $40 \mathrm{M}$ bacilli per $\mathrm{ml}$ of Lepromin-A and $100 \mathrm{M}$ bacilli per $\mathrm{ml}$ of Lepromin- $\mathrm{H}$. The average readings for Lepromin-A and $-\mathrm{H}$ were $6.9 \mathrm{~mm}$ and $6.3 \mathrm{~mm}$ respectively. This study suggests that with the paucity in supply of Lepromin-H, Lepromin-A can be used as a good substitute in concentrations of $40 \mathrm{M}$ bacilli per $\mathrm{ml}$ in comparison with the Lepromin- $\mathrm{H}$ using $100 \mathrm{M}$ bacilli per $\mathrm{ml}$.
\end{abstract}

\section{Introduction}

The Mitsuda lepromin reaction is an important indicator of the ability of the host to mount a cell mediated immune response to Mycobacterium leprae. The lepromin test was described by Hayashi ${ }^{1}$ and Mitsuda. ${ }^{2}$ The standard Mitsuda lepromin reaction is read after 3-4 weeks. A reading of more than $5 \mathrm{~mm}$ is taken as positive. The preparation of lepromin has been standardized by WHO. ${ }^{3}$ Studies ${ }^{4,5}$ have suggested that the lepromin test was one of the most useful indicators to determine the risk of relapse in patients treated with Dapsone monotherapy.

It is becoming increasingly difficult to obtain human lepromatous leprosy tissue to prepare Mitsuda lepromin. However, lepromin prepared from armadillo tissue is now becoming more easily available. ${ }^{6}$ If lepromin is to be used as a criterion to determine the treatment and release from control of patients, then armadillo lepromin will have to be used. This study compares the Mitsuda lepromin reactions using armadillo (Lepromin-A, $40 \mathrm{M}$ bacilli per $\mathrm{ml}$ ) and human lepromin (Lepromin- $\mathrm{H}, 40$ and $100 \mathrm{M}$ bacilli per $\mathrm{ml}$ ). 


\section{Materials and methods}

This present study is on 2 groups of leprosy patients of all classifications. The first group of 37 patients received both human and armadillo lepromin in concentrations of $40 \mathrm{M}$ bacilli per $\mathrm{ml}$. The second group of 60 patients were given $40 \mathrm{M}$ bacilli per ml of Lepromin-A and $100 \mathrm{M}$ bacilli per ml of Lepromin- $\mathrm{H}$.

Three of the larger clinic sub-centres of the Schieffelin Leprosy Research and Training Centre in Karigiri, Gudiyatham Taluk were chosen for the study. This area has been previously described. ${ }^{7}$ Patients of all classifications were randomly chosen for the study.

Human lepromin (Lepromin-H) injections of $0.1 \mathrm{ml}$ and armadillo lepromin (Lepromin-A) were given intradermally. The injections were randomized to one or other arm by use of calculator generated random numbers. Each patient received both human and armadillo lepromin, either in the left or right arm. The lepromin readings were taken 4 weeks later by a minimum of 2 , up to a maximum of 6 observers according to availability. The observers were all paramedical staff or medical officers belonging to the leprosy control unit who had had previous experience and training in the reading of the lepromin test.

Neither the patients nor the observers knew which arm had been given Lepromin-A or Lepromin-H. One arm was read at a time and the readings noted by the chief investigator or the senior paramedical worker who assisted in the study. The observers were not allowed to compare the reading of both arms before recording their results.

Lepromin-H containing $40 \mathrm{M}$ bacilli per $\mathrm{ml}$ was obtained from the National Institute of Medical Research Laboratories, Mill Hill, London, UK. Lepromin-A of the same strength, $40 \mathrm{M}$ bacilli per ml, was obtained from WHO Headquarters, Geneva. Lepromin-H of concentration $100 \mathrm{M}$ bacilli per ml, was prepared at the Laboratories of the Schieffelin Leprosy Research and Training Centre, according to standard protocol suggested by the World Health Organization. ${ }^{3}$

\section{Results}

\section{STUDY 1}

The age, sex and type of leprosy in the 37 patients who received $0.1 \mathrm{ml}$ of human and armadillo lepromin of the concentration $40 \mathrm{M}$ bacilli per $\mathrm{ml}$ is given in Table 1. Their average lepromin readings according to age and type are given in Table 2. The average Mitsuda lepromin readings using the armadillo lepromin (Lepromin-A) was consistently higher than the human lepromin (Lepromin-H) readings (Table 2).

The results were analysed by the technique of Nested 2-way analysis of variance, ${ }^{8}$ using the individual readings. There was no significant difference in 
Table 1.

\begin{tabular}{|c|c|c|c|c|c|c|c|c|c|c|}
\hline & \multicolumn{5}{|c|}{ Study $1^{*}$} & \multicolumn{5}{|c|}{ Study $2 \dagger$} \\
\hline & $\begin{array}{l}0-14 \\
\text { years }\end{array}$ & $\begin{array}{l}15-24 \\
\text { years }\end{array}$ & $\begin{array}{c}25 \text { years and } \\
\text { above }\end{array}$ & Total & & $\begin{array}{l}0-14 \\
\text { years }\end{array}$ & $\begin{array}{l}15-24 \\
\text { years }\end{array}$ & $\begin{array}{c}25 \text { years and } \\
\text { above }\end{array}$ & Total & \\
\hline IND $\mathrm{M} / \mathrm{F}$ & - & - & $1 / 1$ & $1 / 1$ & 2 & - & $1 / 0$ & $0 / 1$ & $0 / 2$ & 2 \\
\hline TT & $2 / 3$ & $1 / 1$ & $4 / 3$ & $7 / 7$ & 14 & $3 / 3$ & $4 / 5$ & $5 / 7$ & $12 / 15$ & 27 \\
\hline BT & - & - & $4 / 8$ & $4 / 8$ & 12 & $1 / 0$ & $2 / 2$ & $9 / 4$ & $12 / 6$ & 18 \\
\hline $\mathrm{BL}$ and $\mathrm{LL}$ & - & $0 / 1$ & $5 / 3$ & $5 / 4$ & 9 & $0 / 1$ & $3 / 0$ & $7 / 2$ & $10 / 3$ & 13 \\
\hline Total & $2 / 3$ & $1 / 2$ & $14 / 15$ & $17 / 20$ & 37 & $4 / 4$ & $10 / 7$ & $21 / 14$ & $24 / 26$ & 60 \\
\hline
\end{tabular}

* Distribution- of the 37 patients in Study 1.

+ Distribution of the 60 patients in Study 2.

Study 1: Lepromin-A and -H, 40 M bacilli per ml; Study 2: Lepromin-A $40 \mathrm{M}$ and Lepromin-H $100 \mathrm{M}$ bacilli per $\mathrm{ml}$.

IND, Indeterminate; TT, Tuberculoid; BT, Borderline Tuberculoid, BL; LL, Borderline Lepromatous and Lepromatous; $\mathrm{M} / \mathrm{F}$, Number of males/females.

reading between the sexes or ages. The Lepromin-A readings however were statistically significantly higher $(P<0.001)$ than the Lepromin-H readings. The overall average lepromin reading using Lepromin-A was $4.7 \mathrm{~mm}$ and Lepromin$\mathrm{H} 2 \cdot 1 \mathrm{~mm}$.

\section{STUDY 2}

A similar method of analysis as for Study 1 was used. Table 1 gives the age, sex and type of leprosy in the 60 patients who received $0.1 \mathrm{ml}$ of Lepromin- $\mathrm{H}$ of concentration $100 \mathrm{M}$ bacilli per $\mathrm{ml}$ and $0.1 \mathrm{ml}$ of Lepromin-A, concentration of $40 \mathrm{M}$ bacilli per $\mathrm{ml}$. The average lepromin readings of the 60 patients, by age and type are given in Table 2. This table shows that the lepromin readings using Lepromin-A and - $\mathrm{H}$ were very similar. There was no significant difference in the readings when the ages and sexes were compared. When the lepromin readings using Lepromin-A and $-\mathrm{H}$ were analysed as in Study 1, there was no significant difference in the readings. The overall average Mitsuda lepromin reading using Lepromin-A was $6.9 \mathrm{~mm}$ and the average lepromin reading using Lepromin- $\mathrm{H}$ was $6 \cdot 3 \mathrm{~mm}$.

\section{Discussion}

One study ${ }^{9}$ using similar concentrations of Lepromin-A (175 $\mathrm{M}$ bacilli per $\mathrm{ml}$ ) and Lepromin-H (160 M bacilli per $\mathrm{ml})$, reported an exaggerated response in 
Table 2. Average lepromin reading by age and type ( $\mathrm{mm})$

\begin{tabular}{|c|c|c|c|c|c|c|c|c|c|c|c|c|c|c|}
\hline \multirow[b]{2}{*}{ Study } & \multirow[b]{2}{*}{ Lepromin } & \multirow[b]{2}{*}{ Type } & \multirow{2}{*}{$\begin{array}{c}\text { No. of } \\
\text { patients }\end{array}$} & \multicolumn{2}{|c|}{$0-14$ years } & \multirow{2}{*}{ No. of } & \multicolumn{2}{|c|}{ 15-24 years } & \multirow{2}{*}{$\begin{array}{l}\text { No. of } \\
\text { patients }\end{array}$} & \multicolumn{2}{|c|}{$\begin{array}{c}25 \text { years } \\
\text { and above }\end{array}$} & \multirow{2}{*}{$\begin{array}{l}\text { No. of } \\
\text { patients }\end{array}$} & \multicolumn{2}{|c|}{ Total } \\
\hline & & & & ${ }^{*} \mathrm{~A}$ & ${ }^{*} \mathrm{H}$ & & ${ }^{*} \mathrm{~A}$ & ${ }^{*} \mathrm{H}$ & & ${ }^{*} \mathrm{~A}$ & ${ }^{*} \mathrm{H}$ & & ${ }^{*} \mathrm{~A}$ & ${ }^{*} \mathrm{H}$ \\
\hline & & IND & - & - & - & - & - & - & 2 & $6 \cdot 8$ & $3 \cdot 5$ & 2 & $6 \cdot 8$ & $3 \cdot 5$ \\
\hline \multirow{5}{*}{1} & $\mathrm{~A}$ and $\mathrm{H} 40 \mathrm{M}$ & TT & 5 & $5 \cdot 7$ & $3 \cdot 1$ & 2 & $7 \cdot 5$ & $3 \cdot 9$ & 7 & $7 \cdot 6$ & $2 \cdot 9$ & 14 & $6 \cdot 9$ & $3 \cdot 1$ \\
\hline & bacilli per $\mathrm{ml}$. & BT & - & - & - & - & - & - & 11 & 4.9 & $2 \cdot 1$ & 11 & 4.9 & $2 \cdot 1$ \\
\hline & & $\mathrm{BL}+\mathrm{LL}$ & - & - & - & 1 & $0 \cdot 0$ & $0 \cdot 0$ & 9 & $1 \cdot 0$ & $0 \cdot 4$ & 10 & 0.9 & $0 \cdot 3$ \\
\hline & Total No. & & 5 & & & 3 & & & 29 & & & 37 & $4 \cdot 7$ & $2 \cdot 1+$ \\
\hline & & IND & - & - & - & 1 & $5 \cdot 8$ & $5 \cdot 8$ & 1 & $4 \cdot 7$ & $7 \cdot 3$ & 2 & $5 \cdot 3$ & $6 \cdot 6$ \\
\hline \multirow[t]{4}{*}{2} & A $40 \mathrm{M}$ & TT & 6 & $8 \cdot 6$ & $7 \cdot 3$ & 9 & $10 \cdot 8$ & $10 \cdot 7$ & 12 & $9 \cdot 7$ & $8 \cdot 4$ & 27 & $9 \cdot 8$ & 8.9 \\
\hline & $\begin{array}{l}\text { bacilli per ml. } \\
\text { H } 100 \mathrm{M} \text { bacilli }\end{array}$ & BT & 1 & $8 \cdot 4$ & $5 \cdot 6$ & 4 & $7 \cdot 3$ & $6 \cdot 5$ & 13 & $6 \cdot 4$ & $5 \cdot 7$ & 18 & $6 \cdot 3$ & $5 \cdot 8$ \\
\hline & per ml. & $\mathrm{BL}+\mathrm{LL}$ & 1 & $0 \cdot 4$ & $0 \cdot 0$ & 3 & $0 \cdot 0$ & $0 \cdot 7$ & 9 & $2 \cdot 5$ & 1.9 & 13 & $1 \cdot 8$ & 1.5 \\
\hline & Total No. & & 8 & & & 17 & & & 35 & & & 60 & 6.9 & $6 \cdot 3 t$ \\
\hline
\end{tabular}

IND, Indeterminate; TT, Tuberculoid; BT, Borderline Tuberculoid; BL + LL, Borderline Lepromatous and Lepromatous. * Average lepromin readings $(\mathrm{mm})$; † Overall average of readings. 
patients receiving Lepromin-A. Using the same concentration of Lepromin-A and $-\mathrm{H}(160 \mathrm{M}$ bacilli per $\mathrm{ml})$ another study ${ }^{10}$ also obtained an exaggerated result in individuals receiving Lepromin-A.

Three double blind trials " were carried out to determine the late reactivity of 103 leprosy patients and unaffected persons to different concentrations of human and armadillo lepromin. They suggested that a concentration of armadillo lepromin of $1 \mathrm{M}$ bacilli per $\mathrm{ml}$ would be best for routine work in comparison with the human lepromin. A study ${ }^{6}$ reviewing the work of comparative studies of human and armadillo lepromin, states that several workers have shown concordance of Mitsuda reaction evoked by Lepromin-A and Lepromin-H.

A study ${ }^{12}$ of 41 leprosy patients using Lepromin- $\mathrm{H}$ in concentration of $80 \mathrm{M}$ bacilli per $\mathrm{ml}$ and Lepromin-A $40 \mathrm{M}$ bacilli per $\mathrm{ml}$, found that the Mitsuda lepromin reading was significantly higher using Lepromin- $\mathrm{H}$.

In the present study the Mitsuda lepromin readings using $40 \mathrm{M}$ bacilli per $\mathrm{ml}$ of Lepromin- $\mathrm{A}$ and $-\mathrm{H}$, were significantly different. The average reading of Lepromin- $\mathrm{H}$ and $-\mathrm{A}$ were 4.7 and $2 \cdot 1$, respectively. However, the lepromin readings using Lepromin-A, $40 \mathrm{M}$ bacilli $\mathrm{ml}$ and Lepromin-H $100 \mathrm{M}$ bacilli per $\mathrm{ml}$ were similar (6.90 versus $6.3 \mathrm{~mm})$, and not statistically different.

This study suggests that for obtaining comparative readings in human and armadillo lepromin, a concentration of $40 \mathrm{M}$ bacilli per $\mathrm{ml}$, of Lepromin-A compares favourably with $100 \mathrm{M}$ bacilli per $\mathrm{ml}$ of Lepromin- $\mathrm{H}$. Thus, for routine use of the lepromin test, the above strengths are recommended.

Previous studies at Karigiri ${ }^{4}$ indicated that lepromin reaction is one of the most important criteria for determining the risk of relapse in paucibacillary leprosy. It was also suggested that lepromin positivity could be used as a criterion to determine chemotherapeutic regimens. The important constraint however was the unavailability of Lepromin- $\mathrm{H}$. This study provides rationale for the possible substitution of Lepromin-A in the concentration of $40 \mathrm{M}$ bacilli per ml, instead of Lepromin-H concentration $100 \mathrm{M}$ bacilli per ml. Field studies are planned to evaluate this possibility.

\section{Acknowledgments}

We wish to thank all the staff of the Schieffelin Leprosy Research and Training Centre who assisted in the project, especially those of the Department of Epidemiology and Leprosy Control. We would also like to thank Mr J Samuel and Mr P Samuel for their help, the smear technicians who participated in the project and $\mathrm{Mr} \mathrm{N}$ Christopher Vethakan and $\mathrm{Mr}$ Lewis Kumar for their secretarial assistance. We also wish to thank Dr Richards and Mr Jayaseelan of the Department of Bio-statistics, Christian Medical College, Vellore for their statistical help and advice. 


\section{References}

1 Hayashi Y. On a pure culture of leprosy bacilli and skin reaction by means of the pure culture suspension. Saikingaku Zasshi (J Bacteriol) 1918; 272: 51-2 (Japanese). English translation, Int J Lepr, 1953; 21: 370-2.

Mitsuda K. On the value of a skin reaction to a suspension of leprous nodules. Jap .J Dermat, 1919; Vol. 19: 697-708. English translation, Int J Lepr, 1953; 21: 347-58.

3 World Health Organization. A guide to leprosy control, WHO/79.7, p. 55.

${ }_{4}^{4}$ Jesudasan $\mathrm{K}$, et al. Relapse rates among paucibacillary leprosy patients released from control. Int. J Lepr, 1984; 52: 304-310.

5 Jesudasan K, Christian M. The lepromin test and number of patches-useful indicators to determine risk of relapse in paucibacillary leprosy. Paper read at Ind Assoc Leprologist's Conference November 1983, Bombay.

6 Waters J, Kirchheimer. Demand and supply of Lepromin-A. An overvicw. Lepr India, 1982; 52 (3): 525-9.

7 Karat ABA, Rao PSS. Epidemiological studies in Gudiyatham Taluk. Part I. Lepr Rev, 1967; 38: 77-82.

* Armitage P. Statistical Methods in medical research. Blackwell Scientific Publications, London 1977 p. 253-9.

9 Meyers WM, Kvemes S, Binford $\mathrm{CH}$. Comparison of reaction to human and armadillo lepromin in leprosy. Int J Lepr, 1975; 43 (3): 218-25.

10 Miller JW, Ganonon C, Chan SCP. Comparison in leprosy patients of Fernandez and Mitsuda reactions using human and armadillo antigens-A double blind study. Int J Lepr, 1975; 43 (3): 226-38.

$"$ Bechelli LM et al. Double blind trial to determine the reactivity of leprosy patients and unaffected persons to different concentration of armadillo lepromin in comparison to human lepromin. Int J Lepr, 1980; 48 (2): 126.

12 Kumar B et al. Lepromin-H versus Lepromin-A. Ind J Lepr, 1984; 56 (1): 50-7. 